http://www.zoobank.org/References/F8A1590C-92F9-4732-BAF8-E26283D31E96

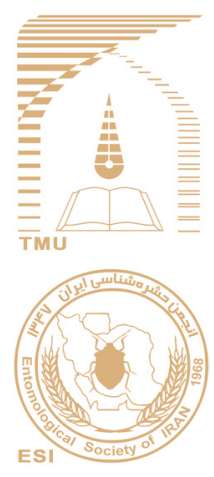

\title{
Additional notes to the morphology of Hyperaspis pseudopustulata Mulsant, 1853 (Coleoptera: Coccinellidae)
}

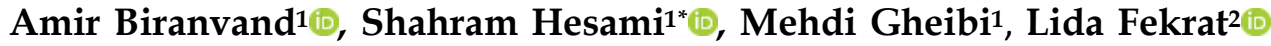 \& Oldřich Nedvěd 3}

1 Department of Entomology, College of Agricultural Sciences, Shiraz Branch, Islamic Azad University, Shiraz, Iran.amir.beiran@gmail.com; s_hesami@yahoo.com; mehgheibi@yahoo.com

2 Department of Plant Protection, Faculty of Agriculture, Ferdowsi University of Mashhad, Mashhad, Iran. fekra@@ferdowsi.um.ac.ir

3 Faculty of Science, University of South Bohemia, Branišovská 1760, 37005 České Budějovice, Czech Republic. nedved@prf.jcu.cz

ABSTRACT. The ladybird Hyperaspis pseudopustulata Mulsant, 1853 was recently reported as the $13^{\text {th }}$ species of the genus Hyperaspis of Iran. Because of the lack of sufficient details in the original description, here we provide more

Received:

19 May, 2020 details of morphological features by the help of electron microscope and quantitative morphometric measurements of Iranian $H$. pseudopustulata. The differential characters of the species in comparison with other close species are

Accepted:

28 October, 2020 presented.

Published:

07 November, 2020

Subject Editor:

Hiva Naserzadeh

Key words: morphology, ladybird, Hyperaspis, taxonomy, SEM

Citation: Biranvand, A., Hesami, Sh., Gheibi, M., Fekrat, L. \& Nedvěd, O. (2021) Additional notes to the morphology of Hyperaspis pseudopustulata Mulsant, 1853 (Coleoptera: Coccinellidae). Journal of Insect Biodiversity and Systematics, 7 (1), 67-73.

\section{Introduction}

The genus Hyperaspis Chevrolat, 1836 is the type genus of the tribe Hyperaspidini Mulsant (Coleoptera: Coccinelliade). The species of the genus mostly feed on coccids and sometimes on aphids (Gordon \& Canepari, 2008). The species H. pseudopustulata Mulsant, 1853 occurs in the Western Palearctic. It was recently reported from Iran by Biranvand et al. (2020), increasing the total number of species of the genus known from Iran (reviewed by Biranvand et al., 2017) to thirteen.

The previous descriptions of the species were short, superficial and qualitative. In the current study, more detailed and quantitative description of this species are presented. Images of adults and male genitalia of Iranian individuals of H.pseudopustulata are illustrated, detailed morphological characters of this species are described using both light and scanning electron microscopy (SEM). Morphometric measurements are provided that will enable future comparison with those of other populations and with other species of the genus Hyperaspis and thus will make their identification more reliable.

Corresponding author: Shahram Hesami, E-mail: s_hesami@yahoo.com

Copyright (C) 2021, Biranvand et al. This is an open access article distributed under the terms of the Creative Commons Attribution License (CC BY 4.0), which permits unrestricted use, distribution, and reproduction in any medium, provided the original author and source are credited. 


\section{Material and methods}

Samples of $H$. pseudopustulata used in this study were collected by Samira Karimi on Eryngium sp. in the village Khiaran (Kermanshah province, Iran). The species was identified using available identification keys (Canepari et al., 1985; Biranvand et al., 2017). External morphology was observed with a stereo microscope (Olympus SZ-ST). The specimens were boiled in a 10\% solution of $\mathrm{KOH}$ for several minutes depending on the darkness of the body color. The dissected genitalia were then transferred into distilled water for a maximum of 10 minutes to rinse off the $\mathrm{KOH}$. Eventually, the microscopic slides were prepared using Hoyer's medium. Images were photographed with iPhone 8 plus camera. The SEM photographs were made using electron microscope at the Islamic Azad University, Khorramabad. The photos were then cleaned up and laid out in plates with CorelDRAW Graphics Suite 12.0 and measurements were performed in Adobe Photoshop CS 8.0. All measurements were performed only on two male specimens, while exact dimensions for females must be completed in another study.

\section{Results}

Hyperaspis pseudopustulata Mulsant, 1853

Material examined: IRAN, Kermanshah province, village Khiaran, August 2017, $2 \hat{\jmath} \hat{0}$ on Eryngium sp. (near E. thyrsoides), leg.: S. Karimi, det. A. Biranvand \& O. Nedvěd.

Morphology: Body oval and convex. Body length $2.85 \mathrm{~mm}$, which falls within the range 2.5-3.8 $\mathrm{mm}$ the reported by Biranvand et al. (2017), while Nedvěd (2015) indicated only rough values 3-4 mm. Body width $2.20 \mathrm{~mm}$, the ratio of length/width 1.30, while Nedverd (2015) indicated 1.4 (Fig. 1A).

Head: Mouthparts and antennae yellow-brown. Antennae short, less than interocular distance, with 10 antennomeres (Fig. 1D), last three antennomeres form a loose club. The last and the penultimate antennomeres with many sensilla (sensilla basilonica and sensilla chaetica, compare with Hao et al. (2020)). Eyes finely faceted, hairs between ommatidia short (less than ommatidium diameter) and sparse (about one hair per three ommatidia).

Thorax: Prosternal process with converging carinae that meet at $25 \%$ of the prosternum length. Metasternal postcoxal lines complete, ending at the lateral margin of sternum, length of hairs inside the line as long as the diameter of a puncture in which they grow, length of hairs just behind the line 1-2x diameter of a puncture, other metasternal hairs 2$3 \times$ diameter of a puncture. Pronotum mostly black with red lateral margins, wide $0.76 \times$ maximum body width. Pronotum and elytra apparently glabrous, but with tiny hairs about the length as the punctures diameter, laid down (not erect). Punctures have a form of transversal grooves. Scutellum large, $0.14 \times$ maximum width of body, $0.76 \times$ as long as wide.

Trochanter with a posterior tooth that forms more than $1 / 3$ of the width of trochanter. Femur short, stout, $1.76 \times$ as long as trochanter, about $0.37 \times$ as wide as long. Tibia $0.84 \times$ as long as femur, the tarsal groove $0.32 \times$ tibia length, surrounded by 15 thick bristles on its anterior side. Tarsi cryptotetramerous (Fig. 2E), the $4^{\text {th }}$ segment longer than length of the other tarsomeres together. Tarsal claw with a basal tooth in half of the length of the claw (Fig. 2F), tooth about one half of the entire width of the claw.

Elytra black, rather matt, with an orange red spot on the distal ends, in $7 / 8$ of the elytra length, near lateral margins (Fig. 3I). Males with an additional small orange triangular spot on the humeral corner of elytra. 

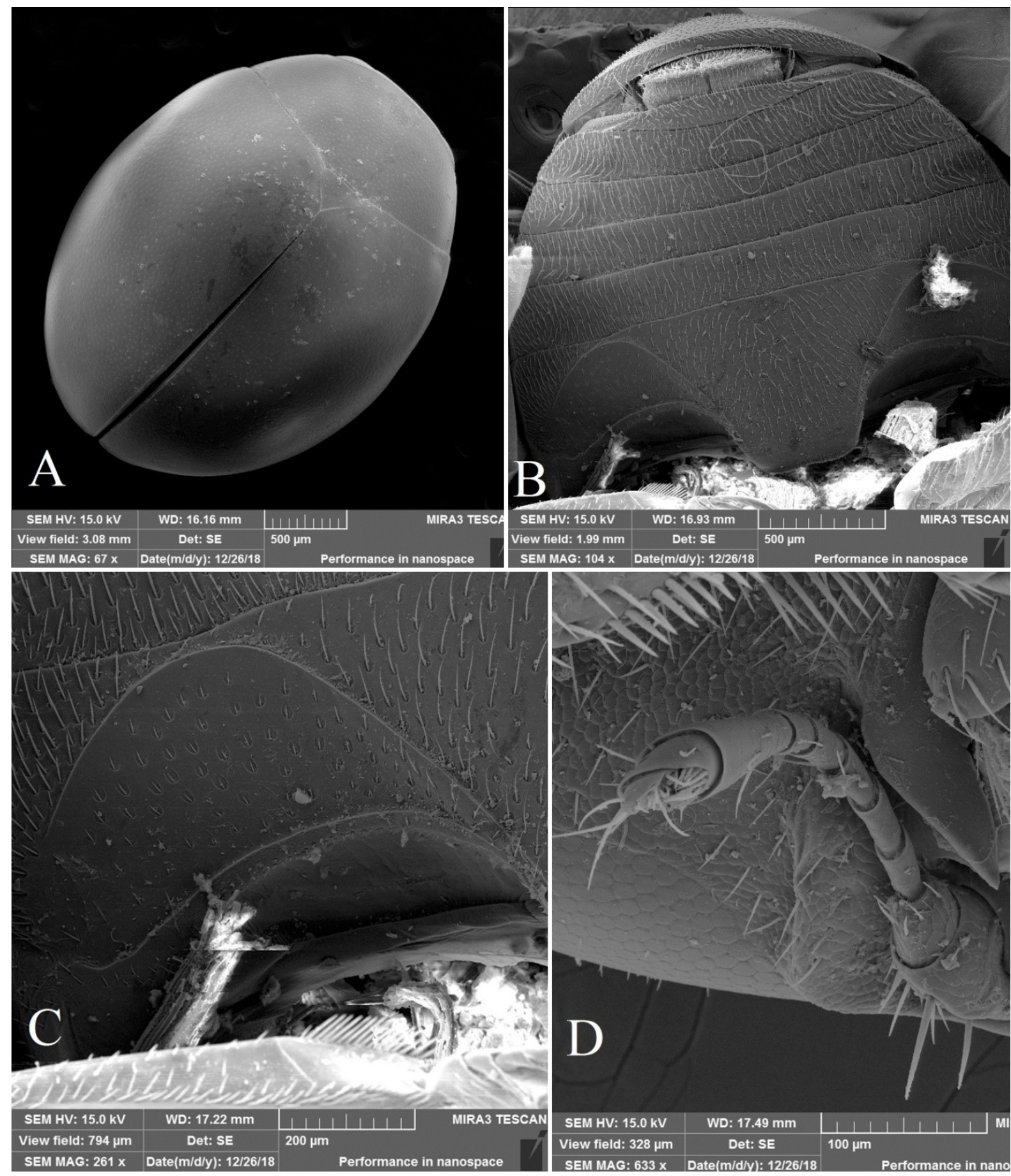

Figure 1. Morphological characters of Hyperaspis pseudopustulata. A. Dorsal view; B. Abdominal ventrites; C. Abdominal ventrite 1 with postcoxal line; D. Antenna.

Abdomen: With six ventrites (Fig. 1B). Abdominal postcoxal line incomplete and distinctly recurved (Fig. 1C), turning at more than $90 \%$ of the minimum length of the first ventrite. Hairs inside the line about $1 / 3$ of the length of the hairs outside the line, about the diameter of the punctures in which they grow. Mid and hind legs yellow in males, brown in females (see Nedvěd, 2015). Tegmen (Figs. 2G-H, 3L-N) is a feature that distinguishes H. pseudopustulata 
from $H$. reppensis (that has large sharp median tooth on the penis guide and its apical angle $>80^{\circ}$ ) and $H$. duvergeri (that has blunt apical angle and curved longitudinal inner line). Penis guide shorter than parameres $(0.87 \times), 2.63 \times$ as long as wide, with a low blunt tubercle in the middle, with sharp apical angle $60-70^{\circ}$, and straight longitudinal inner line. Penis (Fig. 3J) very slender, with distal third straight, with triple slightly widened apex (Fig. 3K).

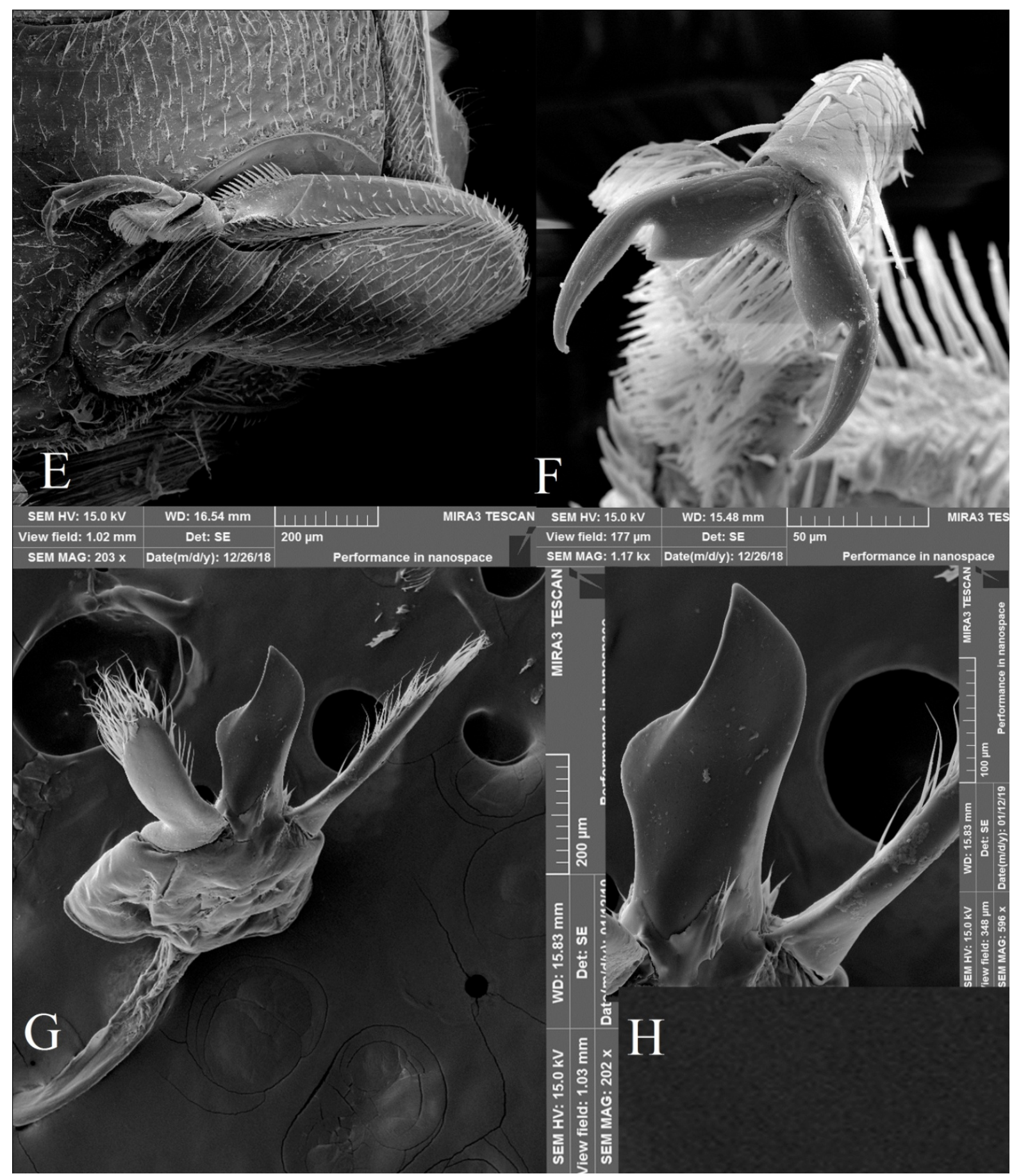

Figure 2. Morphological characters of Hyperaspis pseudopustulata (male). E. Mid leg; F. Tarsal claws with subquadrate tooth; G. Tegmen; H. Penis guide of tegmen. 

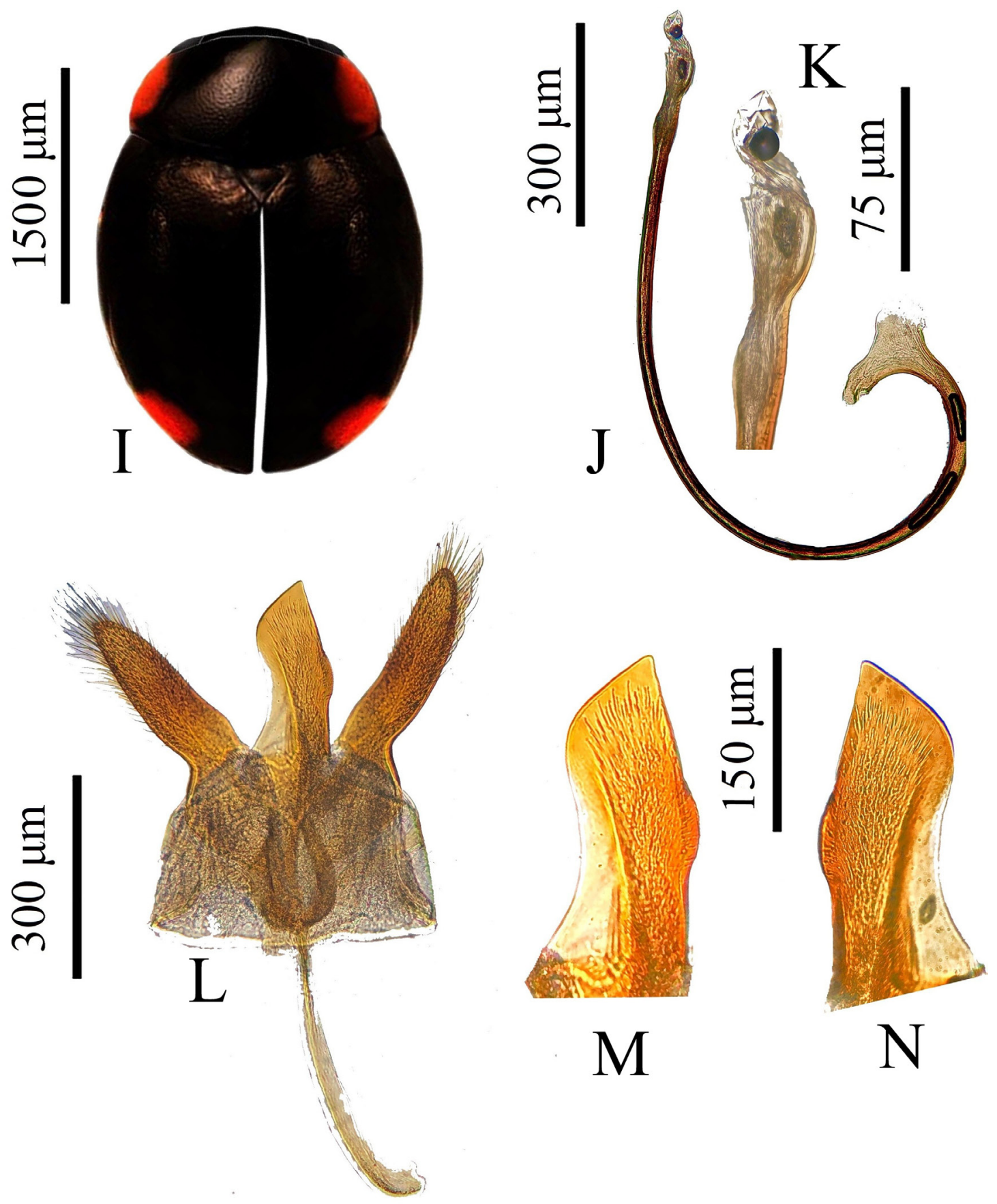

$\mathrm{N}$

Figure 3. Morphological characters of Hyperaspis pseudopustulata (male). I. dorsal view; J. penis; K. penis apex; L. tegmen; M-N. penis guide of tegmen at various angles.

\section{Discussion}

Unlike $H$. pseudopustulata, $H$. concolor Suffrian has uniformly black body on dorsal surface and has no spots on elytra. Some species of the genus Hyperaspis such as H. femorata (Motschulsky, 1837), H. histeroides (Faldermann, 1837), H. marmottani (Fairmaire, 1868), $H$. persica Duverger, 1983, H. polita Weise, 1885, H. quadrimaculata Redtenbacher, 1843, 
H. syriaca Weise, 1885, H. transversoguttata Weise, 1878 and H. vinciguerrae Capra, 1929 have more than one spot on each elytra. However, Hyperaspis duvergeri Fürsch, 1985 and H. reppensis (Herbst, 1783) have similar single red spot on each elytra and accurate identification requires dissection of genitalia.

Hyperaspis pseudopustulata is mainly distributed in Europe; in Asia it has been reported from Kazakhstan, Turkey and Asian parts of Russia (Kovář, 2007). While it has been reported from semiaquatic plants in Europe (Nedvěd, 2015), the record on Eryngium in Iran means that this species can be adapted to dry grassland.

\section{Acknowledgments}

This research was funded by the Czech Science Foundation (grant no. 20-10003S to O. Nedvěd). The authors want to thank Dr. Jahanshir Shakarami (Lorestan University, Khorramabad, Iran) and Dr. Hassanali Vahedi (Razi University, Kermanshah, Iran) for providing some specimens and SEM assistance.

\section{Conflict of Interests}

The authors declare that there is no conflict of interest regarding the publication of this paper.

\section{ORCID}

Amir Biranvand: https:/ / orcid.org/0000-0001-9953-064X

Shahram Hesami: https:/ / orcid.org/0000-0002-8537-409X

Lida Fekrat: https:// orcid.org/0000-0002-5189-9488

Oldřich Nedvěd: https:/ / orcid.org/0000-0001-9932-3456

\section{References}

Biranvand, A., Tomaszewska, W., Nedvěd, O., Khormizi, M. Z., Nicolas, V., Canepari, C., Shakarami, J., Fekrat, L. \& Fürsch, H. (2017) Review of the tribe Hyperaspidini Mulsant (Coleoptera: Coccinellidae) from Iran. Zootaxa, 4236 (2), 311-326. https:/ / doi.org/10.11646/zootaxa.4236.2.6

Biranvand, A., Nedvĕd, O., Karimi, S., Vahedi, H., Hesami, Sh., Lotfalizadeh, H., Ajamhasani, M. \& Ceryngier, M. (2020) Parasitoids of the ladybird beetles (Coleoptera: Coccinellidae) in Iran: an update. Annales de la Société entomologique de France (N.S.), 56, 1-9.

https://doi.org/10.1080/00379271.2020.1717378

Canepari, C., Fürsch, H. \& Kreissl, E. (1985) Die Hyperaspis-Arten von Mittel, West- und Südeuropa. Systematik undverbreitung (Coleoptera Coccinellidae). Giornale Italiano di Entomologia, 9 (2), 223-252.

Gordon, R.D. \& Canepari, C. (2008) South American Coccinellidae (Coleoptera), Part XI: a systematic revision of Hyperaspidini (Hyperaspidinae). Annali del Museo Civico di Storia Naturale "G. Doria", 99, 245-512.

Hao, Y.N., Sun, Y.X. \& Liu, C.Z. (2020) Functional morphology of the mouthparts of lady beetle Hippodamia variegata (Coleoptera: Coccinellidae), with reference to their feeding mechanism. Zoomorphology, 139, 199-212. https:// doi.org/10.1007/s00435-019-00474-0

Kovár̆, I. (2007) Coccinellidae. In: Löbl, I. \& Smetana, A. (Eds.) Catalogue of Palaearctic Coleoptera. Vol. 4. Elateroidea, Derodontoidea, Bostrichoidea, Lymexyloidea, Cleroidea, Cucujoidea. Apollo Books, Stentrup, pp. 71-74, 568-630.

Nedvěd, O. (2015) Ladybird Beetles (Coccinellidae) of Central Europe. Zoological Keys. Praha: Academia. 303 pp. 
Hyperaspis pseudopustulata Mulsant, 1853 يادداشت تكميلى بر ويزكىهاى ريختشناسى (Coleoptera: Coccinellidae)

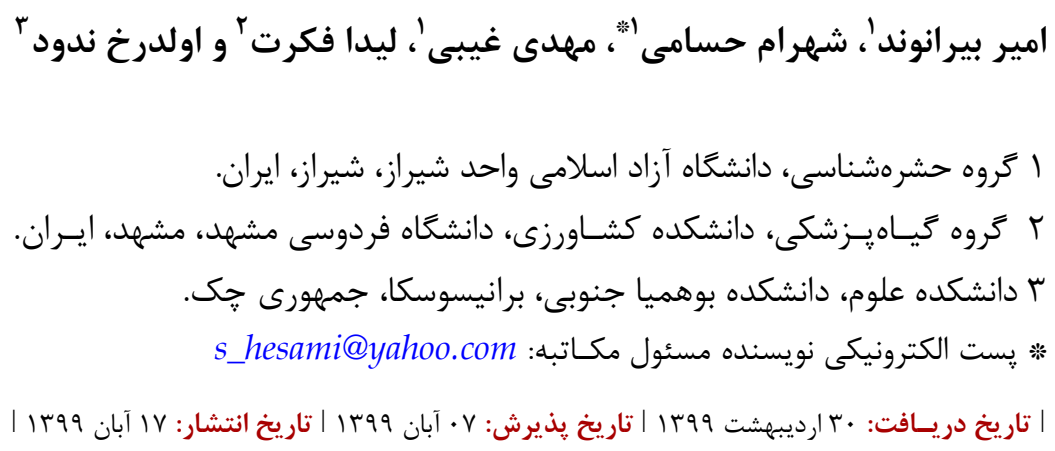

جكيـده: كفشدوزك Hyperaspis pseudopustulata Mulsant، اخيراً به عنوان سيزدهمين كونه از جنس Hyperaspis در ايران كزارش شده است. به ديه دليل كمبود

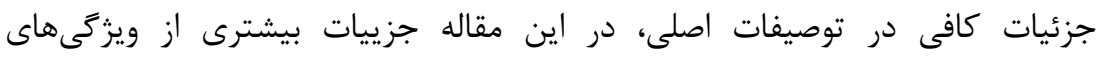

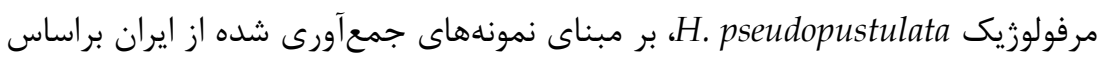
مطالعات ميكروسكوٍ نورى و الكترونى و اندازمكيرىهاى مورفومتريك، ارايه شد.

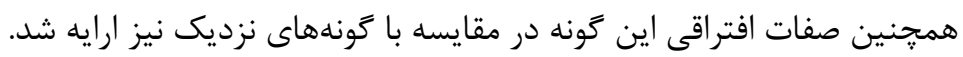
وازَّـان كليدى: مرفولوزى، كفشدوزى، Hyperaspis، تاكسونومى، تصوير روبشى 